\title{
Prognostic and predictive value of EGFR in head and neck squamous cell carcinoma
}

\author{
Paolo Bossi ${ }^{1}$, Carlo Resteghini ${ }^{1}$, Nicholas Paielli ${ }^{1}$, Lisa Licitra ${ }^{1}$, Silvana Pilotti ${ }^{2}$ and \\ Federica Perrone ${ }^{2}$ \\ ${ }^{1}$ Head and Neck Cancer Medical Oncology Department, Fondazione IRCCS Istituto Nazionale dei Tumori, Milan, Italy \\ ${ }^{2}$ Laboratory of Experimental Molecular Pathology, Department of Pathology, Fondazione IRCCS Istituto Nazionale dei Tumori, \\ Milan, Italy \\ Correspondence to: Paolo Bossi, email: paolo.bossi@istitutotumori.mi.it \\ Keywords: EGFR; head and neck squamous cell cancer; prognostic factors; predictive factors; radiotherapy \\ Received: March 25, $2016 \quad$ Accepted: August 12, $2016 \quad$ Published: August 19, 2016
}

\section{ABSTRACT}

EGFR is an extensively studied biomarker in head and neck squamous cell carcinoma (HNSCC). In this review, we discuss the prognostic and predictive role of EGFR in HNSCC, focusing on the different molecular alterations in specific treatment modalities such as radiotherapy alone (RT), combination of surgery, RT and chemotherapy (CT), EGFR inhibitors. We considered EGFR at different molecular levels: protein expression, protein activation, gene copy number, polymorphisms, mutation, EGFRvIII expression and EGFR ligand expression.

Considering RT alone, evidence supports the predictive and prognostic role of high EGFR expression only when evaluated by quantitative assays: this may help select the patients who can mostly benefit from accelerated treatment. Conversely, no predictive biomarkers are available when treatment is a combination of surgery, CT and RT. For this combined treatment, several studies indicate that EGFR expression represents a good prognostic parameter only when measured by a "quantitative" or at least semi-quantitative method. With respect to EGFR inhibitors, neither EGFR expression nor increased gene copy number represent prognostic/predictive factors.

If validated, nuclear EGFR, TGFa levels, EGFR phopshorylation and polymorphisms could represent additional prognostic factors in relation to combination of surgery, CT and RT, while EGFR polymorphisms and high amphiregulin levels could have prognostic value in patients treated with EGFR inhibitors.

\section{INTRODUCTION}

Head and neck squamous cell carcinoma (HNSCC) represents the sixth most frequent cancer worldwide with an incidence of 560,000 cases/year and over 350,000 deaths annually [1]. Treatment of locally-advanced HNSCC requires a multidisciplinary approach involving surgery followed by radiation (RT) with or without chemotherapy (CT) or curative RT with concomitant CT or anti-EGFR agents. TP53 gene status [2, 3] and HPV [4] are the most studied biological markers with known prognostic value. The extensive studies of HPV have paved the way for tailored therapeutic strategies, with the aim of sparing toxicities in HPV-positive tumors and intensifying treatment in HPV-negative cancers.

As observed also for other malignancies, an extensively studied biomarker in HNSCC is the epidermal growth factor receptor (EGFR), a cell surface receptor member of the ErbB family. Activation of EGFR leads to a phosphorylation cascade mediated via tyrosine kinases which works downstream through the PI3KPTEN-AKT, MAPK, ERK, and Jak/STAT pathways and promotes proliferation, invasion, angiogenesis, and metastatic spread. Evidence of EGFR activity has been reported in HNSCC cell lines, as well as in a high percentage of primary HNSCC [5-7]. Aberrant activation of EGFR signaling in HNSCC may be achieved by several mechanisms, including overexpression of EGFR and its ligands, establishing autocrine/paracrine loops, EGFR gene amplification, EGFR mutation/polymorphism and transactivation by other receptor tyrosine kinases (RTKs). The relevance of EGFR pathway in HNSCC led to the successful development of cetuximab in both the curative 
Table 1: Main studies on EGFR protein expression as prognostic and predictive factor in HSCC.

\begin{tabular}{|c|c|c|c|c|c|}
\hline Study & Population & Treatment & Method & $\begin{array}{l}\text { Prognostic value of high } \\
\text { EGFR }\end{array}$ & $\begin{array}{l}\text { Predictive value } \\
\text { of high EGFR }\end{array}$ \\
\hline \multicolumn{6}{|l|}{ Radiotherapy } \\
\hline Chang 2008 & $\mathrm{n}=50$, glottic SCC & $\begin{array}{l}\text { Primary conventional fractionated or } \\
\text { hypofractionated RT }\end{array}$ & IHC assay & $\begin{array}{l}\text { Impact on recurrence, } \\
\text { TTP }\end{array}$ & - \\
\hline Parik 2007 & $\mathrm{n}=123$, laryngeal $\mathrm{SCC}$ & Primary RT & IHC assay & No impact on OS, LRR & - \\
\hline Wen 1996 & $\mathrm{n}=68$, laryngeal $\mathrm{SCC}$ & RT & IHC assay & No impact on OS, RR & - \\
\hline Nichols 2012 & $\mathrm{n}=75$, laryngeal $\mathrm{SCC}$ & RT & IHC assay & No impact on OS, LRR & - \\
\hline Aebersold 2002 & $\mathrm{n}=95$, oropharyngeal SCC & primary RT & IHC assay & $\begin{array}{l}\text { No impact on OS, DFS, } \\
\text { LTC }\end{array}$ & - \\
\hline Lassen 2013 & $n=336$, oropharyngeal SCC & primary RT & IHC assay & $\begin{array}{l}\text { No impact on OS, DFS, } \\
\text { LRC }\end{array}$ & - \\
\hline Ryott 2009 & $\mathrm{n}=78$, oral tongue $\mathrm{SCC}$ & Preoperative RT & IHC assay & No impact on $\mathrm{pCR}$ & - \\
\hline Ang 2002 & $\mathrm{n}=155, \mathrm{HNSCC}$ & primary RT & SAMBA system & Impact on OS, DFS, LRR & - \\
\hline Chung 2011 & $\mathrm{n}=533, \mathrm{HNSCC}$ & $\begin{array}{l}\text { Accelerated or standard fractionated } \\
\text { RT }\end{array}$ & SAMBA system & $\begin{array}{l}\text { Impact on OS, LRR, PFS } \\
\text { in both arms }\end{array}$ & $\begin{array}{l}\text { No impact on } \\
\text { OS, PFS, LRR in } \\
\text { accelerated RT } \\
\text { arm }\end{array}$ \\
\hline Bentzen 2005 & $n=304$ HNSCC & $\begin{array}{l}\text { CHART vs conventional fractionated } \\
\text { RT }\end{array}$ & IHC assay & - & $\begin{array}{l}\text { Impact on LRC in } \\
\text { the CHART arm }\end{array}$ \\
\hline Eriksen 2005 & $\begin{array}{l}n=209 \text {, supraglottic larynx } \\
\text { SCC }\end{array}$ & $\begin{array}{l}\text { Primary RT, OTT: } 91 / 2,61 / 2 \text { or } 5 \frac{1}{2} \text {, } \\
\text { weeks }\end{array}$ & IHC assay & - & $\begin{array}{l}\text { Impact on LRC } \\
\text { in the arms with } \\
\text { OTT } 6 \frac{1}{2} \text { or } 5 \frac{1}{2} \\
\text { weeks }\end{array}$ \\
\hline \multicolumn{6}{|c|}{ Surgery, chemotherapy, radiotherapy } \\
\hline Ranelletti 2001 & Laryngeal SCC & Surgery +/- RT & Binding assay & Impact on OS & - \\
\hline Dassonville 1993 & $\mathrm{n}=109, \mathrm{HNSCC}$ & CT & Binding assay & $\begin{array}{l}\text { Impact on OS, relapse } \\
\text { free }\end{array}$ & - \\
\hline Magné 2001 & $\begin{array}{l}\mathrm{n}=77 \text {, oro and hypopharynx } \\
\text { SCC }\end{array}$ & Non accelerated $\mathrm{RT}+\mathrm{CT}$ & Binding assay & Impact on OS, TTF & - \\
\hline Etienne 1999 & $\mathrm{n}=82$, advanced $\mathrm{HNSCC}$ & Preoperative CT +/- RT & Binding assay & Impact on OS & - \\
\hline Pivot 2005 & $\mathrm{n}=71$, hypo and larynx SCC & Preoperative CT; primary RT & Binding assay & Impact on OS, DFS & - \\
\hline Almadori 1999 & $n=140$ laryngeal $\mathrm{SCC}$ & Surgery +/- RT & Binding assay & $\begin{array}{l}\text { Impact on neck node } \\
\text { relapse }\end{array}$ & - \\
\hline Maiorano 1998 & $\mathrm{~N}=100$ oral cavity SCC & surgery & IHC assay & Impact on DFS, OS & \\
\hline Grandis 1998 & $\mathrm{n}=91, \mathrm{HNSCC}$ & Surgery +/- RT +/- CT & SAMBA system & Impact on DFS & - \\
\hline Psyrri 2005 & $\mathrm{n}=67$, oropharyngeal $\mathrm{SCC}$ & Primary RT; surgery and RT +/- CT & AQUA & \begin{tabular}{|llr} 
Impact & on response \\
(nuclear & EGFR), LRR, \\
DFS & \\
\end{tabular} & - \\
\hline Pectasides 2011 & $\mathrm{n}=64, \mathrm{HNSCC}$ & Primary RT or surgery + RT & AQUA & Impact on OS & - \\
\hline Szabo 2011 & $\mathrm{n}=71, \mathrm{HNSCC}$ & Surgery & IHC assay & Impact on OS & - \\
\hline Kontic 2015 & $\mathrm{n}=185$, laryngeal $\mathrm{SCC}$ & surgery & IHC assay & Impact on OS & - \\
\hline Huang 2012 & $\mathrm{n}=160$, oral cavity SCC & surgery & IHC assay & Impact on DFS, OS & - \\
\hline Monteiro 20012 & $\mathrm{n}=67$, oral cavity $\mathrm{SCC}$ & Surgery +/- RT & IHC assay & Impact on OS, DFS & - \\
\hline Farhadied 2009 & $\mathrm{n}=106$, laryngeal SCC & Surgery +/- RT & IHC assay & Impact on OS; DFS; LRR & - \\
\hline Laimer 2007 & 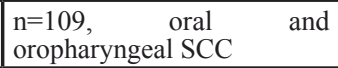 & Surgery $+/-\mathrm{CT}+/-\mathrm{RT}$ & IHC assay & Impact on OS & - \\
\hline Wheeler 2012 & $\mathrm{n}=154, \mathrm{HNSCC}$ & Surgery +/- RT or CRT & IHC assay & Impact on OS, PFS & - \\
\hline Lindquist 2012 & $\mathrm{n}=62$, oropharyngeal $\mathrm{SCC}$ & Preoperative RT $+/$ - surgery & IHC assay & Impact on OS & - \\
\hline Jiang 2009 & Laryngeal SCC & Surgery + RT & IHC assay & No impact on OS LRC & - \\
\hline Nakata 2011 & $\mathrm{n}=89$, oral tongue $\mathrm{SCC}$ & Surgery & IHC assay & $\begin{array}{l}\text { No impact on DFS and } \\
\text { OS }\end{array}$ & - \\
\hline Lundberg 2012 & $\mathrm{n}=130, \mathrm{HNSCC}$ & Surgery +/- RT +/- CT & IHC assay & No impact on DFS & - \\
\hline Ongkeko 2005 & $\begin{array}{l}\mathrm{n}=44 \text {, pharynx and larynx } \\
\text { SCC }\end{array}$ & Surgery & IHC assay & No impact on DFS & - \\
\hline Carracedo 2008 & $\begin{array}{l}\mathrm{n}=47 \text {, pharynx and larynx } \\
\mathrm{SCC}\end{array}$ & Surgery & IHC assay & No impact on OS, relapse & - \\
\hline Won 2012 & $\begin{array}{l}\mathrm{n}=121 \text {, oral and oropharyn- } \\
\text { geal SCC }\end{array}$ & Surgery +/- RT +/- CT & IHC assay & No impact on RFS & - \\
\hline Trivedi 2011 & $\mathrm{n}=135$, oral $\mathrm{SCC}$ & Surgery +/- RT +/- CT & IHC assay & No impact on OS, RFS & - \\
\hline Shah 2009 & $\mathrm{n}=89$, oral $\mathrm{SCC}$ & Surgery $+/-\mathrm{RT}+/-\mathrm{CT}$ & IHC assay & No impact on OS, RFS & - \\
\hline Diniz.feitas 2007 & $\mathrm{n}=44$, oral $\mathrm{SCC}$ & surgery & IHC assay & No impact on OS & - \\
\hline Shiraki 2005 & $n=140$, oral SCC & surgery & IHC assay & No impact on OS & - \\
\hline
\end{tabular}




\begin{tabular}{|c|c|c|c|c|c|}
\hline Rahimi 2012 & $\mathrm{n}=106$, oropharyngeal SCC & $\mathrm{IMRT}+\mathrm{CT}$ & IHC assay & $\begin{array}{l}\text { No impact on OS, DFS, } \\
\text { LRC }\end{array}$ & - \\
\hline Szentkuti 2015 & $\mathrm{n}=226, \mathrm{HNSCC}$ & unknown & IHC assay & No impact on OS & - \\
\hline Keren 2014 & Meta-analysis 37 studies & Surgery +/-RT+/-CT & IHC assay & Impact on OS & - \\
\hline Numico 2010 & $n=122$, HNSCC & $\mathrm{CT}$ or surgery $+\mathrm{CT}$ & IHC assay & $\begin{array}{l}\text { No impact on OS, PFS, } \\
\text { LRC }\end{array}$ & - \\
\hline Perisanidis 2013 & $\mathrm{n}=113$, oropharyngeal SCC & Preoperative CRT + surgery & IHC assay & $\begin{array}{l}\text { No impact on OS, } \\
\text { response }\end{array}$ & - \\
\hline Kumar 2008 & $\mathrm{n}=50$, oropharyngeal SCC & Preoperative CT+/-RT & IHC assay & $\begin{array}{l}\text { Impact on response to } \\
\text { induction CT, OS, DSS }\end{array}$ & - \\
\hline Hitt 2005 & $\mathrm{n}=46, \mathrm{HNSCC}$ & Preoperative CT & IHC assay & Impact on DFS and OS & - \\
\hline Hong 2010 & $\mathrm{n}=270$, oropharyngeal $\mathrm{SCC}$ & Surgery; RT; surgery + RT & IHC assay & Impact on LRF & - \\
\hline Reimers 2007 & $\mathrm{n}=80$, oropharyngeal $\mathrm{SCC}$ & Surgery + RT; CRT & IHC assay & No impact on DFS, OS & - \\
\hline Young 2011 & $\mathrm{n}=240, \mathrm{HNSCC}$ & CRT & IHC assay & No impact on FFS, OS & - \\
\hline Shi 2009 & $\mathrm{n}=111$, oropharyngeal SCC & RT; CRT & IHC assay & No impact on OS, DFS & - \\
\hline Kong 2009 & $\mathrm{n}=82, \mathrm{HNSCC}$ & RT; CRT; surgery +/- RT+/-CRT & IHC assay & Impact on OS & - \\
\hline Vainshtein 2014 & $\mathrm{n}=198$, oropharyngeal SCC & CRT & IHC assay & No impact on LRF & - \\
\hline \multicolumn{6}{|l|}{ EGFR inhibitors } \\
\hline Hitt 2012 & $\begin{array}{l}\mathrm{n}=33, \text { recurrent and/or } \\
\text { metastatic HNSCC }\end{array}$ & Paclitaxel + Cetuximab & IHC assay & \begin{tabular}{|l|} 
No impact on response, \\
PFS, OS
\end{tabular} & - \\
\hline Tinhofer 2011 & $\begin{array}{l}\mathrm{n}=47, \text { recurrent and/or } \\
\text { metastatic HNSCC }\end{array}$ & Docetaxel + cetuximab & IHC assay & $\begin{array}{l}\text { No impact on DCR, } \\
\text { PFS, OS } \\
\end{array}$ & - \\
\hline Psyrri 2005 & $\mathrm{n}=57, \mathrm{HNSCC}$ & $\mathrm{CT}+/$ - cetuximab & IHC assay & No impact on OS, PFS & \begin{tabular}{|l|} 
Impact on \\
response to cetux- \\
imab
\end{tabular} \\
\hline Ang 2014 & $\mathrm{n}=380 \mathrm{HNSCC}$ & $\mathrm{CRT}+/$ - cetuximab & IHC assay & $\begin{array}{l}\text { No impact on PFS, OS, } \\
\text { LRF }\end{array}$ & - \\
\hline Wheeler 2012 & $\begin{array}{l}\mathrm{n}=39, \text { recurrent } / \text { metastatic } \\
\text { HNSCC }\end{array}$ & $\begin{array}{l}\text { Cisplatin, docetaxel and Cetuximab } \\
+ \text { RT }\end{array}$ & IHC assay & Impact on OS & - \\
\hline Smilek 2012 & $\mathrm{n}=29, \mathrm{HNSCC}$ & RT+ cetuximab & Real time PCR & Impact on pCR & - \\
\hline Psyrri 2014 & $\mathrm{n}=63, \mathrm{HNSCC}$ & $\mathrm{CT}+$ cetuximab+CRT & AQUA & No impact on OS, PFS & - \\
\hline Burtness 2005 & $\mathrm{n}=117, \mathrm{HNSCC}$ & Cisplatin $+/$-Cetuximab & IHC assay & - & \begin{tabular}{|l|} 
Impact on \\
response. No im- \\
pact on PFS,OS
\end{tabular} \\
\hline Licitra 2012 & $\begin{array}{l}\mathrm{n}=411, \text { recurrent and/or } \\
\text { metastatic HNSCC }\end{array}$ & $\begin{array}{l}\text { Cisplatin or carboplatin, } 5 \mathrm{FU}+/- \\
\text { cetuximab }\end{array}$ & IHC assay & - & $\begin{array}{l}\text { No impact on OS, } \\
\text { response, PFS }\end{array}$ \\
\hline Basavaraj 2010 & $\mathrm{n}=92, \mathrm{HNSCC}$ & Cisplatin $+/$ - nimotuzumab & IHC assay & Impact on OS & - \\
\hline Crombet 2004 & $\mathrm{n}=24, \mathrm{HNSCC}$ & RT+nimotuzumab & IHC assay & No impact on OS & - \\
\hline Rodriguez 2010 & $\mathrm{~N}=55, \mathrm{HNSCC}$ & $\mathrm{RT}+/-$ nimotuzumab & IHC assay & - & Impact on OS \\
\hline
\end{tabular}

HNSCC: head and neck squamous cell carcinoma; OS: overall survival; PFS: progression free survival; RT: radiotherapy: CT: chemotherapy: CRT: chemotherapy; IHC: immunohistochemistry; IMRT: intensity modulated RT; RR: recurrence rate: LRR: locoregional relapse; LTC: local tumor control; TTF: time to treatment failure; pCR: pathological complete response; DSS: disease specific survival; RFS: relapse free survival ; -: the prognostic or predictive value of high EGFR expression was not investigated.

and palliative settings $[8,9]$ and to the conduction of several trials with other antibodies directed against EGFR, such as panitumumab, zalutumumab and nimotuzumab [10-13], or RTK inhibitors involving downstream EGFR signaling $[14,15]$.

Several studies have investigated the prognostic and predictive value of EGFR in HNSCC. In this review, we discuss available evidence on this topic, focusing on the different EGFR molecular alterations in tumor tissue, in relation with different treatments and settings.

\section{SEARCH CRITERIA}

To identify the key publications on EGFR prognostic or predictive value in HNSCC, we conducted a comprehensive literature search in the online database
Medline. The search was last updated on October 2015 and included only articles in English, with no limitation on the publication date. Articles were selected for inclusion and assigned to each single treatment section, as judged by the Authors.

Clinical outcome was evaluated in terms of clinical response, overall survival (OS), progression-free survival (PFS), disease-free survival (DFS), locoregional control (LRC), locoregional relapse (LRR), locoregional failure (LRF), disease control rate (DCR) or time to treatment failure (TTF), depending on the reported results of considered studies.

A prognostic biomarker was defined as any tumor characteristic that informs about cancer outcome. In more detail, a biomarker was defined as prognostic when patients with tumor showing a specific characteristic 
Table 2: Main studies on EGFR protein activation as prognostic factor in HSCC

\begin{tabular}{|l|l|l|l|l|}
\hline Study & Population & Treatment & EGFR assay & \begin{tabular}{l} 
Prognostic $\begin{array}{c}\text { value } \\
\text { EGFR activation }\end{array}$ \\
\hline Radiotherapy
\end{tabular} \\
\hline Romanitan 2013 & $\mathrm{n}=8$, oropharyngeal SCC & Accelerated RT & IHC assay & No impact on OS, DFS \\
\hline Surgery, chemotherapy, radiotherapy & $\begin{array}{l}\text { Reverse-phase } \\
\text { protein array }\end{array}$ & Impact on PFS \\
\hline Wheeler 2012 & $\mathrm{n}=67$ frozen HNSCC & Surgery & Western blotting & Impact on relapse \\
\hline Hama 2009 & $\mathrm{n}=82$, frozen HNSCC & Surgery +/- CRT & FRET & Impact on DFS \\
\hline Kong 2006 & $\mathrm{n}=286$ HNSCC & Surgery +/-RT & IHC assay & Impact on OS \\
\hline Szabo 2011 & $\mathrm{n}=71$, HNSCC & surgery &
\end{tabular}

HNSCC: head and neck squamous cell carcinoma; OS: overall survival; PFS: progression free survival; RT: radiotherapy: CRT: chemotherapy; IHC: immunohistochemistry; DFS: disease free survival; FRET: fluorescence resonance energy transfer

have different survival than subjects without that specific characteristic, independently from the treatment [16]. A predictive biomarker was defined as a tumor characteristic that can be used to predict the tumor response to a specific treatment. In particular, the biomarker is considered predictive if the treatment effect is different for patients with tumor showing a specific characteristic compared with patients without that specific characteristic [16]. Therefore, a predictive biomarker can be evaluated only in head-to-head studies presenting both treated and control arms.

In our analysis we considered EGFR at different cytogenetic/molecular levels: protein expression, protein activation, gene copy number, polymorphisms, mutation, EGFRvIII expression and EGFR ligand expression. From identified papers we retrieved prognostic and predictive information regarding EGFR alterations according to the treatment provided. Treatments were grouped as: radiotherapy alone (RT); combination of surgery, RT and chemotherapy (CT); EGFR inhibitors.

\section{CLINICAL EVIDENCE}

\section{EGFR PROTEIN EXPRESSION}

\section{Methods of assessment}

The expression of EGFR protein has been evaluated by several means (Table 1). EGFR immunohistochemistry (IHC), a relatively easy and inexpensive technique, represents the most frequent option; moreover, tissue microarrays enable multiple samples to be stained at once, favoring investigation of biomarkers in large case series of IHC. However, in available studies, EGFR immunoreactivity was heterogeneously evaluated using different cut-off values and following different criteria for intensity and/or extent of the staining, as well as cytoplasmic and/or membranous staining.
Quantitative in situ molecular-based methods have been developed to define EGFR expression by IHC thus avoiding the subjectivity of visual assessment. Another way of determining EGFR expression is the binding assay, a less-used method based on frozen samples processed with radioactive labeled EGF and used to estimate EGFR concentration.

\section{A) RADIOTHERAPY}

\section{Prognosis}

Four different studies [17-20] investigated EGFR expression, evaluated by IHC in laryngeal SCCs treated exclusively with primary RT, as prognostic factor. All but one of these studies reported no association between high EGFR expression and OS or LRC [18-20].

Similarly, an intense EGFR expression assessed by IHC did not influence LRC, DFS and OS in two different series of oropharyngeal SCC patients treated with primary RT [21,22], as well as in response of oral tongue SCCs treated with preoperative RT [23].

By contrast, in two HNSCC series not differentiated by subsite and treated with exclusive RT, EGFR expression was a robust prognostic factor only when a "quantitative" EGFR image analysis-based IHC assay was performed. In one study, EGFR expression, quantitatively evaluated by using the SAMBA system, was a strong independent prognostic indicator, capable to improve the estimation of OS, DFS and LRC applied to pretreatment biopsy specimens from patients assigned to the standard therapy arm receiving conventional RT [24]. The same "quantitative" approach was used in a series of HNSCC patients enrolled into a Phase III trial who received accelerated or standard fractionated RT [25]. Regardless of treatment modalities, high EGFR expression was associated with higher LRR (Relative Risk: 1.91, $P=0.0163$ ) and lower OS (Relative Risk: 1.90, $P=0.0010)$. Collectively, these findings show that high EGFR expression assessed by a quantitative method might 
be a prognostic marker associated with poor outcome of HNSCC patients treated exclusively with RT.

\section{Prediction}

In a series of HNSCC patients enrolled into a Phase III trial who received accelerated or standard fractionated RT, high EGFR expression (quantitatively assessed) showed a trend as independent determinant of OS [hazard ratio (95\% CI for interaction): 0.75 (0.45-1.25)], PFS (hazard ratio (95\% CI for interaction): 0.77 (0.45-1.31) and LRR (hazard ratio (95\% CI for interaction): 0.88 (0.46-1.71)] in the accelerated arm, although statistical significance was not reached [25]. Once again, IHC analysis performed in pretreatment tumor biopsies from HNSCC patients revealed a beneficial role of high EGFR expression in patients assigned to continuous hyperfractionated accelerated RT (CHART) compared with conventionally-fractionated RT [26]. Particularly, among patients showing high EGFR expression (cells with EGFR membrane staining $\geq 25 \%$ ), a significant benefit in 3-year LRC rate was observed in the CHART arm compared with the conventionally-fractionated RT arm. No difference between the two treatment arms was observed in the low EGFR expressing group. However, EGFR expression had no significant effect on OS or distant metastases [26].

Another study suggests the predictive value of EGFR expression in HNSCC patients treated exclusively with RT [27]. Patients with supraglottic larynx SCC were treated with primary RT at the same total dose but with different OTT: $9^{1 / 2}$ weeks, $6^{1 / 2}$ weeks or $51 / 2$ weeks. Using LRC as endpoint, the results showed that patients whose tumors had high EGFR expression at IHC assay benefitted from a reduction in RT overall treatment time from $6 \frac{1}{2}$ to $5 \frac{1}{2}$ weeks more than subjects with low EGFR levels.

Collectively, high EGFR expression may be useful for selecting HNSCC patients who will benefit from accelerated RT in terms of better LRC.

\section{B) COMBINATION OF SURGERY, RADIOTHERAPY AND CHEMOTHERAPY}

\section{Prognosis}

Among the studies that used binding assays, some investigated the role of EGFR within organ preservation strategies such as neoadjuvant $\mathrm{CT}$ followed by RT or concurrent CT/RT. No correlation between EGFR levels and response to these treatments was disclosed. However, with such technique, most studies reported a positive correlation between high concentrations of EGFR and poorer prognosis [28-32]. The binding assay confirmed also EGFR expression to be an independent prognostic factor of neck node relapse in HNSCC patients undergoing surgical resection $\pm \mathrm{RT}[33]$.

The first attempts to establish a relationship between
EGFR expression measured by IHC and PFS and OS were performed by two independent groups several years ago $[34,35]$. In both cases, high EGFR expression was a predictor of reduced DFS and OS at multivariate analysis. However, while Maiorano et al [34] analyzed by EGFR IHC a series of oral cavity SCC treated with surgery and scored samples as positive when presenting at least $10 \%$ of either membranous or cytoplasmic stain, Rubin Grandis et al [35] relied on an automated image analysis system (SAMBA) to quantify EGFR expression by IHC in the primary tumor of patients who underwent surgery $\pm \mathrm{RT}$ and CT.

More recently, the prognostic impact of EGFR protein level measured by quantitative approaches was confirmed by two independent studies which assessed EGFR expression through the AQUA method [36,37]. In particular, Psyrri et al [36] composed a tissue microarray of primary, non-metastatic oropharyngeal SSC treated with primary external beam RT or gross total surgical resection and postoperative RT $( \pm \mathrm{CT})$. The AQUA scoring system showed that patients with high cytoplasmic or nuclear EGFR expression were more likely to experience local recurrence. In a tissue microarray composed of HNSCC treated with CTRT, AQUA analysis revealed EGFR protein levels as a strong predictor of patient outcome [37].

On the other hand, discordant results were obtained when EGFR expression was assessed by IHC without a quantitative approach. In most of the studies involving case series of HNSCC treated with surgery $\pm \mathrm{CT} / \mathrm{RT}$, semi-quantitative criteria were adopted considering both intensity and extent of membranous staining. However, no real concordance in the scoring system across studies was disclosed. For this reason, a direct comparison of different studies could lead to misleading results. Furthermore, these series were published over several decades, with cases treated as late as in the '70s. It is therefore reasonable to assume that the increasing quality of treatment in recent years, especially for what concerns RT, might have influenced outcomes thus introducing other confounding factors in the comparison of these case series. Given these premises, some studies showed a statistical association between clinical outcome and EGFR overexpression [38-44], while other analyses failed to disclose such correlation [45-56]. A recent meta-analysis of 33 studies showed that although HNSCC patients with high EGFR expression had a poorer OS regardless of the type of treatment, a large heterogeneity was reported, mainly related to tumor site and IHC scoring system [57]. With respect to IHC, it is worth mentioning that when the studies were stratified according to the score systems, only the group that evaluated the staining based on a combination of intensity and extent showed significant association between EGFR expression and OS.

Two other studies investigated EGFR expression by IHC as a prognostic factor in patients treated with 
Table 3: Main studies on EGFR gene copy number as prognostic and predictive factor in HSCC

\begin{tabular}{|c|c|c|c|c|c|}
\hline Study & Population & Treatment & EGFR assay & $\begin{array}{l}\text { Prognostic value of } \\
\text { EGFR gain }\end{array}$ & \begin{tabular}{|l|}
\multicolumn{2}{l}{ Predictive } \\
value of \\
EGFR gain \\
\end{tabular} \\
\hline \multicolumn{6}{|l|}{ Radiotherapy } \\
\hline Ryott 2009 & $\mathrm{n}=37$, oral tongue $\mathrm{SCC}$ & Preoperative RT & FISH assay & $\begin{array}{l}\text { No impact on pCR, } \\
\text { OS }\end{array}$ & - \\
\hline \multicolumn{6}{|c|}{ Surgery, chemotherapy, radiotherapy } \\
\hline Chung 2006 & $\mathrm{n}=75, \mathrm{HNSCC}$ & Surgery or biopsy & FISH assay & Impact on PFS, OS & - \\
\hline Temam 2007 & $n=134, \mathrm{HNSCC}$ & Surgery & $\begin{array}{l}\text { Quantitative } \\
\text { real time PCR }\end{array}$ & Impact on DFS, OS & - \\
\hline Nakata 2011 & $\mathrm{n}=89$, oral tongue $\mathrm{SCC}$ & \begin{tabular}{|l} 
Surgery \\
\end{tabular} & FISH assay & Impact on DFS, OS & - \\
\hline Szabo 2011 & $\mathrm{n}=71, \mathrm{HNSCC}$ & \begin{tabular}{|l} 
Surgery \\
\end{tabular} & FISH assay & Impact on OS & - \\
\hline Young 2011 & $\mathrm{n}=240, \mathrm{HNSCC}$ & CRT & FISH assay & Impact on FFS & - \\
\hline Ryott 2009 & $\mathrm{n}=65$, oral tongue $\mathrm{SCC}$ & $\begin{array}{l}\text { Primary RT;surgery } \\
+/- \text { RT and CT }\end{array}$ & FISH assay & No impact on OS & - \\
\hline Pectasides 2011 & $n=102$, HNSCC & $\begin{array}{l}\text { Primary RT; surgery } \\
+ \text { RT }\end{array}$ & FISH assay & No impact on OS & - \\
\hline Wheeler 2012 & $\mathrm{n}=154, \mathrm{HNSCC}$ & $\begin{array}{l}\text { Surgery +/- RT;+/- } \\
\text { CRT }\end{array}$ & FISH assay & No impact on PFS & - \\
\hline Huang 2012 & $n=160$, oral cavity SCC & Surgery & FISH assay & $\begin{array}{l}\text { No impact on OS, } \\
\text { DFS }\end{array}$ & - \\
\hline Dionysopulus 2013 & $\mathrm{n}=253$, larynx SCC & Surgery and/or RT & Real time PCR & $\begin{array}{l}\text { No impact on OS, } \\
\text { DFS }\end{array}$ & - \\
\hline \multicolumn{6}{|l|}{ EGFR inhibitors } \\
\hline Hitt 2012 & $\begin{array}{l}\mathrm{n}=29, \text { recurrent and/or } \\
\text { metastatic HNSCC }\end{array}$ & $\begin{array}{l}\text { Paclitaxel } \\
\text { Cetuximab } \\
\end{array}$ & FISH assay & $\begin{array}{l}\text { No impact on } \\
\text { response, OS,PFS }\end{array}$ & - \\
\hline Argiris 2010 & $\mathrm{n}=39, \mathrm{HNSCC}$ & $\begin{array}{l}\text { Docetaxel+cisplatin } \\
+ \text { Cetuximab }\end{array}$ & FISH assay & $\begin{array}{l}\text { No impact on PFS, } \\
\text { OS }\end{array}$ & - \\
\hline Wheeler 2012 & $\mathrm{n}=39, \mathrm{HNSCC}$ & $\begin{array}{l}\text { Docetaxel+cisplatin } \\
+ \text { Cetuximab+RT }\end{array}$ & FISH assay & No impact on PFS & - \\
\hline Chau 2011 & $\mathrm{n}=45 \mathrm{HNSCC}$ & Erlotinib +cisplatin & FISH assay & $\begin{array}{l}\text { No impact on } \\
\text { response, TTP, OS }\end{array}$ & - \\
\hline Cohen 2010 & $\mathrm{n}=31, \mathrm{HNSCC}$ & $\begin{array}{l}\text { Primary CT }+ \text { CRT }+ \\
\text { Gefitinib }\end{array}$ & FISH assay & Impact on OS & - \\
\hline Licitra 2011 & $\begin{array}{l}\mathrm{n}=312 \text { recurrent and/or } \\
\text { metastatic HNSCC }\end{array}$ & $\begin{array}{l}\text { Platinum/5-FU }+/- \\
\text { cetuximab }\end{array}$ & FISH assay & - & \begin{tabular}{|l} 
No \\
association \\
with \\
response, \\
PFS and OS \\
\end{tabular} \\
\hline
\end{tabular}

HNSCC: head and neck squamous cell carcinoma; OS: overall survival; PFS: progression free survival; RT: radiotherapy: CT: chemotherapy: CRT: chemotherapy; FISH: fluorescent in situ hybridization; FFS: failure free survival; pCR: pathological complete response; DFS: disease free survival; TTP: time to progression; -: the prognostic or predictive value of EGFR gene copy number was not investigated.

combination of CT and RT [58, 59]. They used several different chemotherapeutic agents as well as different scoring system, none of them relying on a quantitative approach. These studies failed in identifying EGFR overexpression as a prognostic factor. A positive study is represented by the work of Kumar et al [60], who prospectively evaluated EGFR expression, together with other markers, in advanced oropharyngeal SCC patients treated with one cycle of cisplatin or carboplatin and fluorouracil. Responders (i.e., those with $50 \%$ response at the primary site) received $\mathrm{CT} / \mathrm{RT}$; non-responders received surgery and RT. EGFR overexpression was associated with poor response to induction CT. Similar results were reported by Hitt et al [61].

The issue of EGFR expression deserves a further comment relative to oropharyngeal cancer, given the strong association between these tumor sites and the presence of HPV conferring a favorable prognosis. Several studies did not investigate HPV infection, therefore potentially altering the evaluation of the prognostic value of EGFR expression. An inverse correlation between HPV positivity and EGFR expression has been reported [22, 50, 
62-68], but the same studies reported discordant results on the prognostic value of EGFR expression.

Few trials $[60,63,64,67]$ evaluated the combined effect of HPV status and EGFR expression on prognosis, showing that the use of EGFR expression in combination with HPV status provides additional prognostic information. The prognosis of patients with EGFRpositive/HPV-negative cancer was the poorest, while the EGFR negative/HPV-positive group showed the best outcome. However, in recent studies on oropharyngeal HNC patients, the prognostic role of EGFR expression was related to the association with HPV-negative tumors, and the added value of EGFR analysis seems to be marginal in respect to $\mathrm{HPV}[22,69]$.

\section{C) EGFR INHIBITORS}

\section{Prognosis}

Some studies have investigated the relation between EGFR expression and the outcome of recurrent/metastatic HNSCC patients treated with anti-EGFR antibody cetuximab [36, 70-72]. Even if limited to restricted series, these investigations consistently showed that EGFR levels detected by IHC have no impact on response, DCR, PFS or OS of patients treated with cetuximab.

By contrast, when EGFR expression was assessed by IHC and real time PCR, a prognostic value for high EGFR expression has been associated with reduced PFS and complete response in cetuximab+RT-treated HNSCC patients, in two studies [73, 74].

However, in a phase II trial of induction CT with weekly cetuximab, paclitaxel, and carboplatin followed by chemoradiation in operable stage III/IV HNSCC, the identification of EGFR by a different approach, i.e. the quantitative AQUA method, confirmed the lack of prognostic value [75].

Last, the percentage of EGFR expression in the tumor cells was significantly associated with better OS in HNSCC patients receiving nimotuzumab in combination with CT [76], by contrast no association between EGFR expression and tumor outcome was observed in advanced HNSCC treated with nimotuzumab in combination with RT [77].

\section{Prediction}

In the EXTREME study, a trend to increased PFS and OS with cetuximab plus chemotherapy was observed for patients with higher IHC scores; however, the low number of patients does not allow any definitive conclusion [78]. The addition of cetuximab was able to counteract the dismal prognosis of the tumors with high EGFR expression showed by the group treated with chemotherapy alone.

Discordant results were obtained in Burtness' trial, in which patients were randomly assigned to receive cetuximab in combination with cisplatin or cisplatin alone [79]. Tumor samples were evaluated for EGFR cytoplasmatic expression by $\mathrm{IHC}$ and among the 52 patients categorized as EGFR low-to-moderate, the response rate was $41 \%$ for those treated with cisplatin plus cetuximab, compared with $12 \%$ for those treated with cisplatin and placebo $(p=0.03)$. Thus, low-moderate EGFR expression seems to predict the response to cetuximab. However, in a logistic regression analysis of response, the interaction between EGFR and treatment group was found not to be significant. By contrast, Psyrri et al reported a correlation between EGFR expression (AQUA method) and response to cetuximab [36]. In a trial of concurrent chemoradiation \pm cetuximab in advanced HNSCC, the analysis was not able to identify EGFR expression as a predictive biomarker because outcomes did not improve by adding cetuximab to RT-cisplatin and did not differ according to EGFR expression [72]. Considering treatment with nimotuzumab, a significant survival improvement was observed in EGFR positive unresectable HNSCC patients treated with this inhibitor and RT compared to control patients receiving placebo and RT [80].

It is worth mention the work by Del Campo et al. who investigated lapatinib in locally advanced HNSCC before chemo-radiotherapy. They reported that IHC EGFR overexpression seems to be predictive; however, the number of responding patients was too low to make any conclusions [81].

On the basis of the above-mentioned discordant data, EGFR expression is neither a prognostic nor a predictive factor in relation to EGFR inhibitors use.

\section{EGFR PROTEIN ACTIVATION}

Whereas many studies investigated the role of total EGFR expression, only few focused on quantitative evaluation of activated receptor (table 2), although phosphorylated EGFR (pEGFR) is thought to be a better biomarker for EGFR pathway activation. pEGFR can be assessed on frozen material by western blotting or reversephase protein and on fixed material by array fluorescence resonance energy transfer (FRET) or IHC.

\section{A) RADIOTHERAPY}

\section{Prognosis}

One recent case series investigated pEGFR expression via IHC on a population of oropharyngeal SCC treated in most cases with accelerated RT [82]. EGFR phosphorylation at residue Tyr1148 and Tyr1068 was detected in $20 \%$ and $47 \%$ of patients, respectively; no association between Tyr1148 or Tyr1068 activation and OS or DFS was observed. Interestingly, pEGFR Tyr1148 and Tyr1068 were associated with absence of HPV infection. 
Table 4: Main studies on EGFR polymorphisms, mutation and EGFR VIII expression as prognostic and predictive factor in HSCC

\begin{tabular}{|c|c|c|c|c|}
\hline \multicolumn{5}{|c|}{ POLYMORPHISMS } \\
\hline Study & Population & Treatment & EGFR assay & Prognostic value \\
\hline \multicolumn{5}{|c|}{ Surgery, chemotherapy, radiotherapy } \\
\hline Nai-Wen Su 2014 & $\mathrm{n}=180, \mathrm{HNSCC}$ & Surgery + CRT & PCR and sequencing & $\begin{array}{l}\text { Impact of EGFR R } 521 \mathrm{~K} \mathrm{G} / \mathrm{G} \text { and } \\
\text { G/A on low OS }\end{array}$ \\
\hline Bandrès 2007 & $n=67$, HNSCC & Surgery and/or CRT & Fluorescent PCR; PCR-RFLP & $\begin{array}{l}\text { Impact of EGFR R521K G/G on } \\
\text { high DRM. No impact of (CA)n } \\
\text { repeat polymorphism in intron } 1 \\
\text { on OS. }\end{array}$ \\
\hline \multicolumn{5}{|l|}{ EGFR inhibitors } \\
\hline klinghammer 2010 & $\mathrm{n}=51, \mathrm{HNSCC}$ & Cetuximab+docetaxel & $\begin{array}{l}\text { PCR-RFLP; PCR and } \\
\text { sequencing }\end{array}$ & $\begin{array}{l}\text { Impact of R521K G/G on DCR } \\
\text { and better PFS. No impact of of } \\
\text { R521K G/G and (CA)n on OS. } \\
\end{array}$ \\
\hline $\begin{array}{l}\text { Stoehlmacher-Williams J } \\
2012\end{array}$ & $\mathrm{n}=48, \mathrm{HNSCC}$ & Cetuximab $+/ \mathrm{CT}$ & PCR-based RFLP & $\begin{array}{l}\text { Impact of } \mathrm{R} 521 \mathrm{~K} \mathrm{G} / \mathrm{G} \text { on longer } \\
\text { OS }\end{array}$ \\
\hline \multicolumn{5}{|c|}{ MUTATION } \\
\hline \multicolumn{5}{|c|}{ Surgery, chemotherapy, radiotherapy } \\
\hline Hama 2009 & $\mathrm{n}=82, \mathrm{HNSCC}$ & Surgery +/- CRT & PCR and sequencing & $\begin{array}{l}\text { Impact on longer survival without } \\
\text { recurrence }\end{array}$ \\
\hline Na 2007 & $\begin{array}{l}\mathrm{n}=108, \text { tongue } \\
\text { and tonsil SCC }\end{array}$ & Surgery and or RT & PCR and sequencing & No impact on OS \\
\hline \multicolumn{5}{|l|}{ EGFR inhibitors } \\
\hline Bahassi 2013 & Case report & \begin{tabular}{|lr} 
Surgery & and \\
RT followed by \\
cetuximab
\end{tabular} & PCR and sequencing & Impact on response \\
\hline Smilek 2012 & $n=29$, HNSCC & RT + cetuximab & Real time PCR & Impact on response \\
\hline \multicolumn{5}{|c|}{ EGFR VIII EXPRESSION } \\
\hline \multicolumn{5}{|l|}{ Surgery } \\
\hline Wheeler 2012 & $\mathrm{n}=49, \mathrm{HNSCC}$ & surgery & Quantitative real time PCR & No impact on PFS \\
\hline Szabo et al. & $\mathrm{n}=71, \mathrm{HNSCC}$ & surgery & $\mathrm{IHC}$ & No impact on OS \\
\hline \multicolumn{5}{|l|}{ EGFR inhibitors } \\
\hline Tinhofer 2011 & $\mathrm{n}=45, \mathrm{HNSCC}$ & docetaxel+cetuximab & $\mathrm{IHC}$ & $\begin{array}{l}\text { impact on treatment response and } \\
\text { PFS }\end{array}$ \\
\hline Chau 2011 & $\mathrm{n}=53, \mathrm{HNSCC}$ & erlotinib+cisplatin & Real time PCR & Impact on better DCR \\
\hline Smilek & $\mathrm{n}=29, \mathrm{HNSCC}$ & cetuximab $+\mathrm{rt}$ & Real time PCR & No impact on treatment response \\
\hline \multicolumn{5}{|c|}{ EGFR LIGAND EXPRESSION } \\
\hline \multicolumn{5}{|l|}{ Radiotherapy } \\
\hline Aebersold 2002 & $\begin{array}{l}\mathrm{n}=95 \\
\text { oropharyngeal } \\
\text { SCC }\end{array}$ & curative rt & $\mathrm{IHC}$ & No impact of TGF $\alpha$ on prognosis \\
\hline Wen 1996 & $\begin{array}{l}\mathrm{n}=68 \text { laryngeal } \\
\mathrm{SCC}\end{array}$ & $\mathrm{rt}$ & $\mathrm{IHC}$ & Impact of TGF $\alpha$ on recurrence \\
\hline \multicolumn{5}{|l|}{ Surgery } \\
\hline Rubin 1998 & $\mathrm{n}=91, \mathrm{HNSCC}$ & surgery $+/$-rt & $\mathrm{IHC}$ & $\begin{array}{l}\text { Impact on DFS, cause specific } \\
\text { survival }\end{array}$ \\
\hline \multicolumn{5}{|l|}{ EGFR inhibitors } \\
\hline Tinhofer 2011 & $n=47$, HNSCC & cetuximab+docetaxel & $\mathrm{IHC}$ & $\begin{array}{l}\text { Impact of amphiregulin on PFS, } \\
\text { OS }\end{array}$ \\
\hline
\end{tabular}

HNSCC: head and neck squamous cell carcinoma; OS: overall survival; PFS: progression free survival; DRM: disease related mortality; DFS: disease free survival; DCR: disease control rate; RT: radiotherapy: CT: chemotherapy: IHC: immunohistochemistry; PCR: polymerase chain reaction; RFLP: restriction fragment length polymorphism 


\section{B) SURGERY, RADIOTHERAPY}

CHEMOTHERAPY,

\section{Prognosis}

Wheeler and colleagues, assessing the phosphorylation specific sites Y992 and Y1068 using reverse-phase protein array, showed that intermediate or high tumor EGFR Y1068, but not Y992, phosphorylation were associated with significantly reduced PFS in a series of frozen HNSCC samples [73]. Notably, in the same series, intermediate/high EGFR Y1068 phosphorylation and intermediate/high EGFR expression were both independently associated with reduced PFS, thus representing potential prognostic indicators. Y1068 pEGFR was confirmed by western blotting in $17 \%$ of HNSCC patients who underwent surgery $\pm \mathrm{CT}$ where EGFR- phosphorylated tumors relapsed significantly earlier than not-phosphorylated ones [83].

Kong et al [84] investigated a large series of HNSCC via FRET, an automated technique able to inform about EGFR phosphorylation status. Of interest, EGFR activation did not correlate with EGFR expression, which in turn was not found to be prognostic.

Last, in a single isolated study, pEGFR assessed by IHC using a specific antibody targeting the phosphotyrosine site 1086 was associated with prolonged survival [38].

\section{C) EGFR INHIBITORS}

\section{Predictivity}

No predictive effect was observed for pre-treatment pEGFR level in patients with locally-advanced HNSCC receiving lapatinib before chemo-radiotherapy [81].

\section{EGFR GENE COPY NUMBER}

In the studies reported in Table 3, EGFR gene status was assessed by FISH, and tumors showing high polysomy of chromosome or EGFR gene amplification were considered to have increased EGFR gene copy number and classified as FISH positive.

\section{A) RADIOTHERAPY}

\section{Prognosis}

In a study on oral tongue SCC patients treated with preoperative RT, high EGFR gene copy number tended to be higher in patients who did not achieve a pathological complete response, even if statistical significance was not reached [23]. The lack of other data does not allow to reach any definite conclusion.

\section{B) SURGERY, RADIOTHERAPY}

\section{CHEMOTHERAPY,}

\section{Prognosis}

A number of studies have investigated the association between EGFR gene status and prognosis in HNSCC patients on different primary treatments, and overall discordant results were obtained.

In some studies, increased EGFR gene copy number was considered as a strong prognostic factor, significantly associated with shorter PFS and OS [38, 46, 65, 84-86].

Interestingly, in all these studies EGFR gene copy number did not correlate either with EGFR protein expression assessed by IHC or EGFR mRNA expression levels detected by microarray or RT-PCR. The fact that $E G F R$ copy number status is a more reliable indicator than EGFR overexpression was confirmed by the observation that patients whose tumors co-exhibited increase of $E G F R$ gene copy number and protein overexpression presented significantly shorter OS than patients with tumors negative for FISH status and positive for EGFR protein overexpression [46]. These results indicate that the alteration of $E G F R$ copy number may not be related only to alterations of EGFR protein expression. Indeed EGFR copy number changes frequently occur in association with chromosome 7 aneusomy that confers worse survival rates. Therefore one possibility is that additional genes on chromosome 7 that are co-amplified with EGFR may be involved in promoting a more aggressive tumor behavior. In line with this hypothesis, in a series of 35 oral SCC patients, Gebhart found that a gain of short arm on chromosome 7 was linked to a higher rate of relapse and worse OS [87]. Alternatively, an increased EGFR copy number may be a surrogate marker of chromosomal instability, which confers an adverse prognosis in many tumors [88]. However, the mechanism by which EGFR FISH status contributes to the oncogenic effect in expressing cells remains unclear.

On the other hand, a number of studies reported lack of association between EGFR gene copy number and OS $[23,37,40,73,89]$. Of note, most of these studies also showed the correlation between $E G F R$ gene copy number and EGFR protein expression levels. Thus, despite some studies are available, the actual prognostic value of the $E G F R$ gene copy number remains controversial. However, when EGFR gene copy number was assessed by FISH, the different scores used to define the FISH-positive and negative cases could explain these inconsistent findings. 
Table 5: Overview of Authors' conclusions.

\begin{tabular}{|c|c|c|c|c|c|c|c|c|c|c|c|c|c|c|}
\hline & \multicolumn{14}{|c|}{ EGFR } \\
\hline & \multicolumn{2}{|c|}{ expression } & \multicolumn{2}{|c|}{ activation } & \multicolumn{2}{|c|}{$\begin{array}{l}\text { copy } \\
\text { number }\end{array}$} & \multicolumn{2}{|c|}{ polimorphisms } & \multicolumn{2}{|l|}{ mutation } & \multicolumn{2}{|c|}{ EGFRvIII } & \multicolumn{2}{|l|}{ ligands } \\
\hline & prog & pred & prog & pred & prog & pred & prog & pred & prog & pred & prog & pred & prog & pred \\
\hline RT & yes & $\begin{array}{l}\text { yes } \\
\text { (accelerated RT) }\end{array}$ & no & n.i. & no & n.i. & n.i. & n.i. & n.i. & n.i. & n.i. & n.i. & d.r. TGF $\alpha$ & n.i. \\
\hline Surgery-CT-RT & yes & n.i. & yes* & n.i. & d.r. & n.i. & yes R521K* & n.i. & no & n.i. & d.r. & n.i. & yes TGFa* & n.i. \\
\hline EGFR inhibitors & d.r. & no & n.i. & n.i. & no & no & yes R521K* & n.i. & $\begin{array}{l}\text { weak } \\
\text { evidence }\end{array}$ & n.i. & d.r. & n.i. & $\begin{array}{l}\text { yes } \\
\text { amphiregulin* }\end{array}$ & n.i. \\
\hline
\end{tabular}

prog: prognostic; pred: predictive; CT: chemotherapy; RT: radiotherapy; d.r.: discordant results; n.i.: not investigated; $*:$ indicative results to be validated

\section{C) EGFR INHIBITORS}

\section{Prognosis}

The results obtained in different cohorts of locallyadvanced or recurrent HNSCC patients treated with cetuximab-based regimens indicate that patients with FISH positive tumors do not show a better response compared with FISH-negative subjects [70] and that EGFR gene status is not associated with PFS or OS [70, 73, 90]. Furthermore, EGFR amplification was not associated with TTP or OS also in HNSCC patients treated in two phase II trials on erlotinib [91]. By contrast, EGFR FISH-positive status was associated with shorter OS in locally-advanced HNC patients receiving CT/RT and gefitinib [92].

\section{Prediction}

The phase III EXTREME study demonstrated that combining cetuximab with platinum-based CT significantly prolonged OS in the first-line treatment of patients with recurrent and/or metastatic HNSCC compared with CT alone. Samples deriving from patients receiving cetuximab plus CT or CT alone were investigated by EGFR FISH to evaluate the role of increased $E G F R$ copy number as predictive biomarker [93]. No correlation between EGFR FISH score and response rate was observed in both study arms: therefore, the results of this unique-to-date study support the lack of utility of EGFR FISH status in predicting the response to cetuximab.

Furthermore, EGFR amplification showed no predictive role in patients treated with lapatinib in locally advanced HNSCC before chemio-radiotherapy [81].

\section{EGFR POLYMORPHISMS}

\section{A) SURGERY, CHEMOTHERAPY, RADIOTHERAPY}

EGFR polymorphisms were uniformly assessed by DNA PCR-based methods. A recent study reported the prognostic role for EGF and EGFR polymorphisms in a cohort of locally-advanced HNSCC patients treated with post-operative CT-RT (Table 4) [94]. In more details, the 5-year OS rates of patients with EGFR R $521 \mathrm{~K} \mathrm{G} / \mathrm{G}$ $(11.1 \%)$ and G/A (15.9\%) were lower than those for the A/A (62.5\%) genotype. Patients carrying one or two unfavorable alleles had worse 5- year OS than those without unfavorable allele (not available versus 20\% versus $71.4 \%, \mathrm{p}=0.002$ ). Multivariate analysis revealed that the highest risk of death was associated with the coexistence of two unfavorable genotypes (hazard ratio $25.7,95 \%$ confidence interval $=3.4-193.4 ; \mathrm{p}=0.002$ ).

The prognostic value of EGFR R521K polymorphism was further investigated in the study of Bandrés et al., where it was defined as R497K according to the older nomenclature [95]. Patients with G/G genotype of the polymorphism R521K in exon 13 showed the highest risk of disease-related mortality. In contrast, in the same patient cohort, the $(\mathrm{CA})_{\mathrm{n}}$ repeat polymorphism in intron 1 was not associated with OS. However, this single study does not allow any firm conclusion.

\section{B) EGFR INHIBITORS}

\section{Prognosis}

Fifty-one recurrent/metastatic HNSCC patients enrolled in a single-arm, phase II study of second-line treatment with cetuximab/docetaxel were genotyped for EGFR polymorphisms R521K in exon 13 and (CA) n repeat. The results revealed that $\mathrm{R} 521 \mathrm{~K} \mathrm{G} / \mathrm{G}$ genotype is significantly associated with increased skin toxicity, DCR and better PFS [96]. However, this genotype had no influence on OS.

However, in HNSCC patients treated with cetuximab $\pm \mathrm{CT}$, the presence of $\mathrm{R} 521 \mathrm{~K} \mathrm{G} / \mathrm{G}$ genotype was associated with longer OS. In detail, the median OS was 6.7 months in patients with at least one $\mathrm{K}$ allele compared with 13.3 months in patients homozygous for the wildtype R allele [97].

The CA repeat polymorphism was not associated with DCR, PFS or OS [96]. 
At present, the promising prognostic value of EGFR R521K G/G polymorphism in patients treated with combination of surgery, CT and RT or EGFR inhibitors deserves further investigations. The predictive role of these polymorphisms has not been investigated yet.

\section{EGFR MUTATION}

EGFR mutation is usually considered a rare event in HNSCC. However, the actual frequency of EGFR mutation is not well defined, even though analogous techniques, mainly PCR and sequencing, have been applied to investigate this issue $[3,98,99]$.

\section{A) SURGERY, CHEMOTHERAPY, RADIOTHERAPY}

\section{Prognosis}

Hama et al [83] prospectively analyzed a population of surgically-treated HNSCC (Table 4). Among 13 patients with EGFR phosphorylation, 4 with EGFR mutation had a longer survival without recurrence than patients with $E G F R$ wild type $(\mathrm{p}=0.023)$. However, the mutational analysis performed on the largest number of cases (17 mutated cases out of 108 total cases) indicated that EGFR mutation is not a significant prognostic factor [99].

\section{B) EGFR INHIBITORS}

\section{Prognosis}

A case report showed complete response in a patient with HNSCC treated with cetuximab monotherapy after initial surgery and RT. The authors identified a somatic mutations in the ligand-binding domain (P546S) and in the kinase domain (R705G) [100]. Interestingly, in vitro experiments indicated that the P546S mutation in the EGFR ligand-binding domain enhances NIH-3T3 cell line sensitivity to cetuximab compared with cells expressing wild-type $E G F R$; on the other hand, R705G mutation did not seem to contribute to drug sensitivity. In another study, a deletion in exon 19 of EGFR was disclosed in two out of 29 HNSCC patients treated with cetuximab and RT. These two patients presented poor clinical outcome, suggesting that this mutation may contribute to the limited response [74].

Despite this intriguing but overall weak evidence, it is rather unlikely that EGFR mutations could provide information about HNSCC response to anti EGFR therapy, mostly due to their low and variable rate in HNSCC.

\section{EGFRVIII EXPRESSION}

\section{A) SURGERY, CHEMOTHERAPY , RADIOTHERAPY}

\section{Prognosis}

EGFRvIII is a mutant form of EGFR due to a deletion of exons 2-7 resulting in a frame deletion variant with a truncated extracellular domain exerting ligandindependent constitutive activity.

Wheeler et al. investigated the expression levels of EGFRvIII mRNA, as detected by real time RT-PCR, in HNSCC patients treated with surgery and/or CT (Table 4) [73]. In this cohort of HPV-negative tumors, intermediate or high EGFRvIII mRNA levels did not provide any prognostic information.

Another study by Szabo et al evaluated EGFRvIII cell expression by IHC in a group of HNSCC patients [38]. Multivariate analysis showed no significant correlation between the presence of EGFRvIII and patient survival.

\section{B) EGFR INHIBITORS}

\section{Prognosis}

Biopsies from patients enrolled in a single-arm phase II study investigating cetuximab plus docetaxel as second-line treatment of recurrent/metastatic HNSCC were analyzed by IHC to measure EGFRVIII expression. EGFRvIII expression was detected in $17 \%$ of cases and there was a significant association between EGFRvIII levels and treatment efficacy. In the group of patients with low EGFRvIII IHC score, DCR was $65 \%$ whereas patients with high EGFRvIII score showed a DCR of $13 \%(p=0.02)$. Multivariate logistic regression analysis confirmed the independent association of EGFRvIII with lack of response and shorter PFS [71]. Moreover, EGFRvIII level, detected by real time PCR, was associated with increased DCR but not with time to progression or OS in recurrent or metastatic HNSCC patients treated with erlotinib [91]. However, Smilek et al reported no association between RT-PCR detected EGFRvIII levels and response to cetuximab combined with RT [74].

It must be emphasized that the presence of EGFRvIII in HNSCC reported in the mentioned studies may be questioned. In fact, two studies recently analyzed a large number of tumors (638 and 531 HNSCC samples) for EGFRvIII expression using IHC with the antibody L8A4, RT-PCR and the RNA-Seq analysis [101, 102]. Both studies provided a strong evidence showing that EGFRvIII is absent or very rare (frequency of $0.37 \%$ ) in HNSCC. In any case, when present, EGFRvIII expression level is low in HNSCC [103] and thus difficult to detect. Cumulatively, 
the different methodologies applied, coupled with the intratumoral heterogeneity, may explain the discordant results and support the notion that an accurate detection of EGFRvIII needs multiple methodologies including DNA, RNA and protein assessment [103].

\section{EGFR LIGAND EXPRESSION}

\section{A) RADIOTHERAPY}

\section{Prognosis}

In a group of patients with oropharyngeal cancer who underwent curative RT, the levels of the EGFR ligand TGF $\alpha$ assessed by IHC in pretreatment tumor biopsies was not a prognostic marker (Table 4) [21]. By contrast, in a group of 68 patients with early laryngeal cancer treated with RT, the recurrence rate was significantly higher in patients with tumor showing TGF $\alpha$ expression detected by IHC [19].

\section{B) SURGERY, CHEMOTERAPY, RADIOTHERAPY}

\section{Prognosis}

TGF $\alpha$ levels were quantified by IHC and computerized image analysis system on primary tumors from HNSCC patients surgically treated ( \pm RT-CT). At multivariate analysis, high TGF $\alpha$ levels were predictors of reduced DFS and disease-related mortality [35].

\section{C) EGFR INHIBITORS}

\section{Prognosis}

Expression of the EGFR ligand amphiregulin was assessed by IHC on biopsies from recurrent/metastatic HNSCC patients treated with cetuximab plus docetaxel. A trend towards a reduction in DCR (40\%) was observed $(p=0.09)$ in patients with high amphiregulin IHC score, as compared with patients with low score (65\%) [71]. In addition, patients that showed high expression of amphiregulin had significantly shorter PFS and OS. Due to the paucity of data, no firm conclusion can be made about the prognostic role of EGFR ligands.

\section{CONCLUSION}

We reviewed the literature on the clinical significance of EGFR alterations in relation to the HNSCC treatment, with the aim to identify emerging prognostic or predictive factors. Our conclusions are summarized in table 5 .
The majority of the trials explored the prognostic role of EGFR alterations, while only limited data exist on the predictive role of EGFR alterations in relation to a specific treatment. At present, the predictive role of this marker has been exclusively explored in HNSCC patients treated with RT or EGFR inhibitors.

Concerning RT, high EGFR expression is a negative prognostic factor associated with poor outcome. Convincing evidence supports the robust predictive role of high EGFR expression when evaluated by a quantitative assay, in order to select patients who can most benefit of accelerated RT.

For HNSCC patients receiving multiple treatments such as surgery, CT and RT or a combination of them, no predictive biomarkers are available. However, several studies indicated that EGFR expression represents a good prognostic parameter, even if there is heterogeneity mainly due to IHC scoring system and tumor site variability. Notably, the significant association of high EGFR expression with shorter PFS and OS was reproducible only when protein expression was measured by a "quantitative" or at least semi-quantitative method. It appears advisable to estimate EGFR protein by a IHC method considering both intensity and extent of the staining, as well as stratifying patients by specific tumor sites. Nuclear EGFR and TGF $\alpha$ levels seem to be additional promising negative prognostic factors, as well as EGFR activation and polymorphisms, however they have not been widely validated yet. EGFR gene copy number as well as EGFR mutations has no prognostic value and do not deserve further investigation.

Within the field of EGFR inhibitors, mainly cetuximab, available studies established that both EGFR expression and an increased gene copy number are neither predictive nor prognostic biomarkers. EGFR polymorphisms and high amphiregulin levels may be promising prognostic factors and validation trials are necessary. However, it must be taken into account that the immune system plays a role in the clinical response to the EGFR inhibitor cetuximab too. Indeed, in addition to the inhibition of downstream signaling pathways, cetuximab mediates its effects also by immunogenic mechanisms such as the antibody-dependent cell mediate cytotoxicity (ADCC), the complement-mediate cytotoxicity, the modulation of the human leukocyte antigen class I and antigen-processing machinery component expression [104]. This fact should be taken into account also considering the emerging role of checkpoint inhibitors in head and neck cancer and the possible synergistic effect of cetuximab and immunotherapeutic drug combinations.

Moreover, when interpreting these data, the inverse relationship between EGFR expression or EGFR increased gene copy number and the stronger prognostic factor of HPV positivity should be taken into account. HPV-positive oropharyngeal tumors tend to present decreased EGFR expression [50, 60, 63, 64, 67, 105], 
and increased EGFR gene copy number is restricted to HPV-negative cancer [3, 65]. Although the rationale underlying those findings has not been fully elucidated yet, it is widely accepted that HPV-positive tumors have a different genetic profile compared with HPV-negative counterparts, thus contributing to the different clinical behavior and to the higher chemo- and radiosensitivity $[68,105,106]$. Therefore, the greater impact of EGFR deregulation in HPV negative tumors should be analyzed within the context of this different genetic pattern, and the "combined" effect of HPV status and EGFR expression on prognosis both of HPV-positive and negative or only of HPV-negative patients remains to be defined.

Lastly, it should be stressed the importance to increase the research regarding the molecular mechanisms underlying EGFR deregulation, in order to improve the HNSCC therapeutic approaches and to reduce the discrepancy sometimes existing between preclinical and clinical data.

\section{ACKNOWLEDGMENTS}

The Authors have no conflicts of interest directly relevant to this manuscript. Editorial assistance for the preparation of this manuscript was provided by Luca Giacomelli, $\mathrm{PhD}$ and Sara Parodi, PhD; this assistance was supported by internal funds.

\section{CONFLICTS OF INTEREST} work.

The author reports no conflicts of interest in this

\section{REFERENCES}

1. Parkin DM, Bray F, Ferlay J, Pisani P. Global cancer statistics, 2002. CA Cancer J Clin. 2005; 55: 74-108.

2. Poeta ML, Manola J, Goldwasser MA, Forastiere A, Benoit N, Califano JA, Ridge JA, Goodwin J, Kenady D, Saunders J, Westra W, Sidransky D, Koch WM. TP53 mutations and survival in squamous-cell carcinoma of the head and neck. N Engl J Med. 2007; 357: 2552-2561.

3. Perrone F, Suardi S, Pastore E, Casieri P, Orsenigo M, Caramuta S, Dagrada G, Losa M, Licitra L, Bossi P, Staurengo S, Oggionni M, Locati L, et al. Molecular and cytogenetic subgroups of oropharyngeal squamous cell carcinoma. Clin Cancer Res. 2006; 12: 6643-6651.

4. Psyrri A, Rampias T, Vermorken JB. The current and future impact of human papillomavirus on treatment of squamous cell carcinoma of the head and neck. Ann Oncol. 2014; 25: 2101-2115.

5. Maxwell SA, Sacks PG, Gutterman JU, Gallick GE. Epidermal growth factor receptor protein-tyrosine kinase activity in human cell lines established from squamous carcinomas of the head and neck. Cancer Res. 1989; 49:
$1130-1137$.

6. Kearsley JH, Kearsley JH, Furlong KL, Cooke RA, Waters MJ. An immunohistochemical assessment of cellular proliferation markers in head and neck squamous cell cancers. Br J Cancer. 1990; 61: 821-827.

7. Ishitoya J, Toriyama M, Oguchi N, Kitamura K, Ohshima M, Asano K, Yamamoto T. Gene amplification and overexpression of EGF receptor in squamous cell carcinomas of the head and neck. Br J Cancer. 1989; 59: 559-562.

8. Bonner JA, Raisch KP, Trummell HQ, Robert F, Meredith RF, Spencer SA, Buchsbaum DJ, Saleh MN, Stackhouse MA, LoBuglio AF, Peters GE, Carroll WR, Waksal HW. Enhanced apoptosis with combination C225/radiation treatment serves as the impetus for clinical investigation in head and neck cancers. J Clin Oncol. 2000; 18: 47S-53S.

9. Vermorken JB, Mesia R, Rivera F, Remenar E, Kawecki A, Rottey S, Erfan J, Zabolotnyy D, Kienzer HR, Cupissol D, Peyrade F, Benasso M, Vynnychenko I, et al. Platinumbased chemotherapy plus cetuximab in head and neck cancer. N Engl J Med. 2008; 359: 1116-1127.

10. Mesía R, Henke M, Fortin A, Minn H, Yunes Ancona AC, Cmelak A, Markowitz AB, Hotte SJ, Singh S, Chan AT, Merlano MC, Skladowski K, Zhang A, et al. Chemoradiotherapy with or without panitumumab in patients with unresected, locally advanced squamouscell carcinoma of the head and neck (CONCERT-1): a randomised, controlled, open-label phase 2 trial. Lancet Oncol. 2015; 16: 208-20.

11. Giralt, Trigo J, Nuyts S, Ozsahin M, Skladowski K, Hatoum G, Daisne JF, Yunes Ancona AC, Cmelak A, Mesía R, Zhang A, Oliner KS, VanderWalde A. Panitumumab plus radiotherapy versus chemoradiotherapy in patients with unresected, locally advanced squamous-cell carcinoma of the head and neck (CONCERT-2): a randomised, controlled, open-label phase 2 trial. Lancet Oncol. 2015; 16: 221-32.

12. Machiels JP, Subramanian S, Ruzsa A, Repassy G, Lifirenko I, Flygare A, Sørensen P, Nielsen T, Lisby S, Clement PM. Zalutumumab plus best supportive care versus best supportive care alone in patients with recurrent or metastatic squamous-cell carcinoma of the head and neck after failure of platinum-based chemotherapy: an openlabel, randomised phase 3 trial. Lancet Oncol. 2011; 12: 333-343.

13. Zibelman M, Mehra R. Overview of Current Treatment Options and Investigational Targeted Therapies for Locally Advanced Squamous Cell Carcinoma of the Head and Neck. Am J Clin Oncol. 2016; 39: 396-406.

14. Bossi P, Locati L, Licitra L. Emerging tyrosine kinase inhibitors for head and neck cancer. Expert Opin Emerg Drugs. 2013; 18: 445-459.

15. Machiels JP, Haddad RI, Fayette J, Licitra LF, Tahara M, Vermorken JB, Clement PM, Gauler T, Cupissol D, Grau JJ, Guigay J, Caponigro F, de Castro G Jr, et al. Afatinib 
versus methotrexate as second-line treatment in patients with recurrent or metastatic squamous-cell carcinoma of the head and neck progressing on or after platinum-based therapy (LUX-Head \& Neck 1): an open-label, randomised phase 3 trial. Lancet Oncol. 2015; 16: 583-594.

16. Ballman KV. Biomarker: predictive or prognostic? J Clin Oncol. 2015; 33: 3968-3971.

17. Chang AR, Wu HG,Park C II, Jeon YK, Kim CW. Expression of epidermal growth factor receptor and cyclin D1 in pretreatment biopsies as a predictive factor of radiotherapy efficacy in early glottis cancer. Head neck. 2008; 30: 852-857.

18. Parikh RR, Yang Q, Haffty BG. Prognostic significance of vascular endothelial growth factor protein levels in T1-2 N0 laryngeal cancer treated with primary radiation therapy. Cancer. 2007; 109: 566-573.

19. Wen QH, Miwa T, Yoshizaki T, Nagayama I, Furukawa M, Nishijima H. Prognostic value of EGFR and TGFalpha in early laryngeal cancer treated with radiotherapy. Laryngoscope 1996; 106: 884-888.

20. Nichols AC, Whelan F, Basmaji J, Dhaliwal S, Dowthwaite S, Chapeskie C, Read N, Palma DA, Fung K, Venkatesan V, Hammond JA, Franklin JH, Siddiqui I, et al. Ki-67 expression predicts radiotherapy failure in early glottic cancer. J Otolaryngol Head Neck Surg. 2012; 41: 124-130.

21. Aebersold DM, Froehlich SC, Jonczy M, Beer KT, Laissue $\mathrm{J}$, Greiner RH, Djonov V. Expression of transforming growth factor- $\alpha$, epidermal growth factor receptor and platelet-derived growth factors A and B in oropharyngeal cancers treated by curative radiation therapy. Radiotherapy Oncol. 2002; 63: 275-283.

22. Lassen P, Overgaard J, Eriksen JG. Expression of EGFR and HPV-associated p16 in oropharyngeal carcinoma: correlation and influence on prognosis after radiotherapy in the randomized DAHANCA 5 and 7 trials. Radiotherapy Oncol. 2013; 108: 489-494.

23. Ryott M, Wangsa D, Heselmeyer-Haddad K, Lindholm J, Elmberger G, Auer G, Avall Lundqvist E, Ried T, MunckWikland E. EGFR protein overexpression and gene copy number increases in oral tongue squamous cell carcinoma. Eur J Cancer. 2009; 45: 1700-1708.

24. Ang KK, Berkey BA, Tu X, Zhang HZ, Katz R, Hammond $\mathrm{EH}, \mathrm{Fu} \mathrm{KK}$, Milas L. Impact of epidermal growth factor receptor expression on survival and pattern of relapse in patients with advanced head and neck carcinoma. Cancer Res. 2002; 62: 7350-7356.

25. Chung CH, Zhang Q, Hammond EM, Trotti AM 3rd, Wang H, Spencer S, Zhang HZ, Cooper J, Jordan R, Rotman MH, Ang KK. Integrating epidermal growth factor receptor assay with clinical parameters improves risk classification for relapse and survival in head-and-neck squamous cell carcinoma. Int. J Radiat Oncol Biol Phys. 2011; 81: 331338.

26. Bentzen SM, Atasoy BM, Daley FM, Dische S, Richman
PI, Saunders MI, Trott KR, Wilson GD. Epidermal growth factor receptor expression in pretreatment biopsies from head and neck squamous cell carcinoma as a predictive factor for a benefit from accelerated radiation therapy in a randomized controlled trial. J Clin Oncol. 2005; 23: 55605567.

27. Eriksen JG, Steiniche T, Overgaard J. The role of epidermal growth factor receptor and E-cadherin for the outcome of reduction in the overall treatment time of radiotherapy of supraglottic larynx squamous cell carcinoma. Acta Oncol. 2005; 44: 50-58.

28. Ranelletti FO, Almadori G, Rocca B, Ferrandina G, Ciabattoni G, Habib A, Galli J, Maggiano N, Gessi M, Lauriola L. Prognostic significance of cyclooxygenase-2 in laryngeal squamous cell carcinoma. Int J Cancer. 2001; 95: 343-349.

29. Dassonville O, Formento JL, Francoual M, Ramaioli A, Santini J, Schneider M, Demard F, Milano G. Expression of epidermal growth factor receptor and survival in upper aerodigestive tract cancer. J Clin Oncol. 1993; 11: 18731878.

30. Magné N, Pivot X, Bensadoun RJ, Guardiola E, Poissonnet G, Dassonville O, Francoual M, Formento JL, Demard F, Schneider M, Milano G. The relationship of epidermal growth factor receptor levels to the prognosis of unresectable pharyngeal cancer patients treated by chemoradiotherapy. Eur J Cancer. 2001; 37: 2169-2177.

31. Etienne MC, Pivot X, Formento JL, Bensadoun RJ, Formento P, Dassonville O, Francoual M, Poissonet G, Fontana X, Schneider M, Demard F , Milano G. A multifactorial approach including tumoural epidermal growth factor receptor, p53, thymidylate synthase and dihydropyrimidine dehydrogenase to predict treatment outcome in head and neck cancer patients receiving 5-fluorouracil. Br J Cancer. 1999; 79: 1864-1869.

32. Pivot X, Magnè N, Guardiola E, Poissonnet G, Dassonville O, Francoual M, Formento Jl, Bensa doun RJ, Demard F, Schneider M, Milano G. Prognostic impact of the epidermal growth factor receptor levels fpr patients with larynx and hypopharynx cancer. Oral Oncol. 2005; 41: 320327.

33. Almadori G, Cadoni G, Galli J, Ferrandina G, Scambia G, Exarchakos G, Paludetti G, Ottaviani F. Epiderrmal growth factor receptor expression in primary laryngeal cancer: an independent prognostic factor of neck node relapse. Int $\mathrm{J}$ Cancer. 1999; 84: 188-191.

34. Maiorano E, Favia G, Viale G. Prognostic implications of epidermal growth factor receptor immunoreactivity in squamous cell carcinoma of the oral mucosa. J Pathol. 1998; 185: 167-174.

35. Rubin Grandis, Melhem MF, Gooding WE, Day R, Holst VA, Wagener MM, Drenning SD, Tweardy DJ. Levels of TGF- $\alpha$ and EGFR protein in head and neck squamous cell carcinoma and patients survival. J Natl Cancer Inst. 1998; 90: 824-832. 
36. Psyrri A, Yu Z, Weinberger PM, Sasaki C, Haffty B, Camp R, Rimm D, Burtness BA. Quantitative determination of nuclear and cytoplasmic epidermal growth factor receptor expression in oropharyngeal squamous cell cancer by using automated quantitative analysis. Clin Cancer Res. 2005; 11: 5856-5862.

37. Pectasides E, Rampias T, Kountourakis P, Sasaki C, Kowalski D, Fountzilas G, Zaramboukas T, Rimm D, Burtness B, Psyrri A. Comparative prognostic value of epidermal growth factor quantitative protein expression compared with FISH for head and neck squamous cell carcinoma. Clin Cancer Res. 2011; 17: 2947-2954.

38. Szabo B, Nelhubel GA, Kàrpàti A, Kenessey I, Jòri B, Szèkely C, Petàk I, Lotz G, Hegedus Z, Hegedus B, Fule T, Dome B, Timar J, et al. Clinical significance of genetic alterations and expression of epidermal growth factor receptor (EGFR) in head and neck squamous cell carcinomas. Oral Oncol. 2011; 47: 487-496.

39. Kontic M, Milovanovic, Colovic Z, Poljak NK, Sundov Z, Sucic A, Pesutic-Pisac. Epidermal growth factor receptor (EGFR) expression in patients with laryngeal squamous cell carcinoma. Eur Arch Otorhinolaryngol. 2015; 272: 401405.

40. Huang SF, Cheng SD, Chien HT, Liao CT, Chen IH, Wang HM, Chuang WY, Wang CY, Hsieh LL. Relationship between epidermal growth factor receptor gene copy number and protein expression in oral cavity squamous cell carcinoma. Oral Oncol. 2012; 48: 67-72.

41. Monteiro LS, Diniz-Freitas M, Garcia-Caballero T, Warnakulasuriya S, Forteza J, Fraga M. Combined cytoplasmic and membranous EGFR and p53 overexpression is a poor prognostic marker in early stage oral squamous cell carcinoma. J Oral Pathol Med. 2012; 41: 559-567.

42. Farhadieh RD, Salardini A, Rees CG, Russell PJ, Yang JL, Smee R. Protein expression of epidermal growth factor receptor in laryngeal squamous cell carcinoma index tumors correlates with diagnosis of second primary tumors of the upper aero-digestive tract. Ann Surg Oncol. 2009; 16: 2888 2894.

43. Laimer K, Spizzo G, Gastl G, Obrist P, Brunhuber T, Fong D, Barbieri V, Jank S, Doppler W, Rasse M, Norer B. High EGFR expression predicts poor prognosis in patients with squamous cell carcinoma of the oral cavity and oropharynx: a TMA-based immunohistochemical analysis. Oral Oncol. 2007; 43: 193-198.

44. Lindquist D, Ahrlund-Richter A, Tarján M, Tot T, Dalianis $\mathrm{T}$. Intense CD44 expression is a negative prognostic factor in tonsillar and base of tongue cancer. Anticancer Res. 2012; 32: 153-161.

45. Jiang H, Yang BB. p53, epidermal growth factor receptor and proliferating cell nuclear antigen in laryngeal squamous cell carcinoma are not predictive markers for the effect of adjuvant radiotherapy. Acta Otolaryngol. 2009; 129: 101107.
46. Nakata Y, Uzawa N, Takahashi K, Sumino J, Michikawa C, Sato H, Sonoda I, Ohyama Y, Okada N, Amagasa T. EGFR gene copy number alteration is a better prognostic indicator than protein overexpression in oral tongue squamous cell carcinomas. Eur J Cancer. 2011; 47: 2364-2372.

47. Lundberg M, Leivo I, Saarilahti K, Mäkitie AA, Mattila PS. Transforming growth factor beta 1 genotype and p16 as prognostic factors in head and neck squamous cell carcinoma. Acta Otolaryngol. 2012; 132: 1006-1012.

48. Ongkeko WM, Altuna X, Weisman RA, Wang-Rodriguez J. Expression of protein tyrosine kinases in head and neck squamous cell carcinomas. Am J Clin Pathol. 2005; 124: 71-76.

49. Carracedo DG, Astudillo A, Rodrigo JP, Suarez C, Gonzalez MV. Skp2, p27kip1 and EGFR assessment in head and neck squamous cell carcinoma: prognostic implications. Oncol Rep. 2008; 20: 589-595.

50. Won HS, Jung CK, Chun SH, Kang JH, Kim YS, Sun DI, Kim MS. Difference in expression of EGFR, pAkt, and PTEN between oropharyngeal and oral cavity squamous cell carcinoma. Oral Oncol. 2012; 48: 985-990.

51. Trivedi TI, Tankshali RA, Goswami JV, Shukla SN, Shah PM, Shah NG. Identification of site-specific prognostic biomarkers in patients with oral squamous cell carcinoma. Neoplasma. 2011; 58: 217-226.

52. Shah NG, Trivedi TI, Tankshali RA, Goswami JV, Jetly DH, Shukla SN, Shah PM, Verma RJ . Prognostic significance of molecular markers in oral squamous cell carcinoma: a multivariate analysis. Head Neck. 2009; 31 : 1544-1556.

53. Diniz-Freitas M, García-Caballero T, Antúnez-López J, Gándara-Rey JM, García-García A. Pharmacodiagnostic evaluation of EGFR expression in oral squamous cell carcinoma. Oral Dis. 2007; 13: 285-290.

54. Shiraki M, Odajima T, Ikeda T, Sasaki A, Satoh M, Yamaguchi A, Noguchi M, Nagai I, Hiratsuka H. Combined expression of p53, cyclin D1 and epidermal growth factor receptor improves estimation of prognosis in curatively resected oral cancer. Mod Pathol. 2005; 18: 1482-1489.

55. Rahimi AS, Wilson DD, Saylor DK, Stelow EB, Thomas CY, Reibel JF, Levine PA, Shonka DC, Jameson MJ, Read PW. p16, Cyclin D1, and HIF-1 $\alpha$ Predict Outcomes of Patients with Oropharyngeal Squamous Cell Carcinoma Treated with Definitive Intensity-Modulated Radiation Therapy. Int J Otolaryngol. 2012; 2012: 685951.

56. Szentkuti G, Danos K, Brauswetter D, Kiszner G, Krenacs, Csako L, Repassy G, Tamas L. Correlation between prognosis and locoregional biomarkers profiles in head and neck squamous cell carcinomas. Pathol Oncol Res. 2015; 21: 643-650.

57. Keren S, Shoude Z, Lu Z, Beibei Y. Role of EGFR as a prognostic factor for survival in head and neck cancer: a meta-analysis. Tumor Biol. 2014; 35: 2285-2295. 
58. Numico G, Russi EG, Colantonio I, Lantermo RA, Silvestris N, Vitiello R, Comino A, Abrate M, Zavattero C, Melano A, Merlano M. EGFR status and prognosis of patients with locally advanced haed and neck cancer tereated with chemotherapy. Anticancer Res. 2010; 30: 671-676.

59. Perisanidis C, Wrba F, Brandstetter A, Korneck G, Mitchell D, Seemann R, Selzer E, Ewers R, Filipits M. Impact of epidermal growth factor receptor, mesenchymalepithelial transition factor, and insuline-like growth factor receptor 1 expression on survival of patients with oral and oropharyngeal cancer. Br J Oral Max Surg. 2013; 51: 234240.

60. Kumar B, Cordell KG, Lee JS, Worden FP, Prince ME, Tran HH, Wolf GT, Urba SG, Chepeha DB, Teknos TN, Eisbruch A, Tsien CI, Taylor JM, et al. EGFR, p16, HPV Titer, Bcl-xL and p53, sex, and smoking as indicator of response to therapy and survival in oropharyngeal cancer. $\mathrm{J}$ Clin Oncol. 2008; 26: 3128-3137.

61. Hitt R, Ciruelos E, Amador ML, Benito A, Sanchez JJ, Ballestin C, Cortes-Funes. prognostic value of the epidermal growth factor receptor (EFGFR) and p53 in advanced head and neck squamous cell carcinoma patients treated with induction chemotherapy. Eur J Cancer. 2005; 41: 453-460.

62. Mirghani H, Amen F, Moreau F, Guigay J, Hartl DM, Lacau St Guily J. Oropharyngeal cancers: relationship between epidermal growth factor receptor alterations and human papillomavirus status. Eur J Cancer. 2014; 50: 11001111.

63. Hong A, Dobbins T, Lee CS, Jones D, Jackson E, Clark J, Armstrong B, Harnett G, Milross C, O'Brien C, Rose B. Relationship between epidermal growth factor receptor expression and human papillomavirus status as markers of prognosis in oropharyngeal cancer. Eur J Cancer. 2010; 46: 2088-2096.

64. Reimers N, Kasper HU, Weissenborn SJ, Stützer H, Preuss SF, Hoffmann TK, Speel EJ, Dienes HP, Pfister HJ, Guntinas-Lichius O, Klussmann JP. combined analysis of HPV-DNA, p16 and EGFR expression to predict prognosis in oropharyngeal cancer. Int J Cancer. 2007; 120: 17311738.

65. Young RJ, Rischin D, Fisher R, McArthur GA, Fox SB, Peters LJ, Corry J, Lim A, Waldeck K, Solomon B. Relationship between epidermal growth factor receptor status, p16(INK4A), and outcome in head and neck squamous cell carcinoma. Cancer Epidemiol Biomarkers Prev. 2011; 20: 1230-1237.

66. Shi W, Kato H, Perez-Ordonez B, Pintilie M, Huang S, Hui A, O’Sullivan B, Waldron J, Cummings B, Kim J, Ringash J, Dawson LA, Gullane P, et al. Comparative prognostic value of HPV16 E6 mRNA compared with in situ hybridization for human oropharyngeal squamous carcinoma. J Clin Oncol. 2009; 27: 6213-6221.

67. Kong CS, Narasimhan B, Cao H, Kwok S, Erickson JP, Koong A, Pourmand N, Le QT. The relationship between human papillomavirus status and other molecular prognostic markers in head and neck squamous cell carcinomas. Int J Radiat Oncol Biol Phys. 2009; 74: 553-561.

68. Seiwert TY, Zuo Z, Keck MK, Khattri A, Pedamallu CS, Stricker T, Brown C, Pugh TJ, Stojanov P, Cho J, Lawrence MS, Getz G, Brägelmann J, et al. Integrative and comparative genomic analysis of HPV-positive and HPVnegative head and neck squamous cell carcinomas. Clin Cancer Res. 2015; 21: 632-641.

69. Vainshtein JM, Spector ME, McHugh JB, Wong KK, Walline HM, Byrd SA, Komarck CM, Ibrahim M, Stenmark MH, Prince ME, Bradford CR, Wolf GT, McLean $\mathrm{S}$, et al. Refining risk stratification for locoregional failure after chemotherapy in human papillomavirus-associated oropharyngeal cancer. Oral Oncol. 2014; 50: 513-519.

70. Hitt R, Irigoyen A, Cortes-Funes H, Grau JJ, Garcia-Saenz JA, Cruz-Hernandez JJ. Phase II study of the combination of cetuximab and weekly paclitaxel in the first-line treatment of patients with recurrent and/or metastatic squamous cell carcinoma of head and neck. Ann Oncol. 2012; 23: 1016-1102.

71. Tinhofer I, Klinghammer K, Weichert W, Knödler M, Stenzinger A, Gauler T, Budach V, Keilholz U. Expression of amphiregulin and EGFRvIII affect outcome of patients with squamous cell carcinoma of the head and neck receiving cetuximab-docetaxel treatment. Clin Cancer Res. 2011; 17 : 5197-5204.

72. Ang KK, Zhang Q, Rosenthal DI, Nguyen-Tan PF, Sherman EJ, Weber RS, Galvin JM, Bonner JA, Harris J, El-Naggar AK, Gillison ML, Jordan RC, Konski AA, et al. Randomized phase III trial of concurrent accelerated radiation plus cisplatin with or without cetuximab for stage III to IV head and neck carcinoma: RTOG 0522. J Clin Oncol. 2014; 27: 29402950.

73. Wheeler S, Siwak DR, Chai R, LaValle C, Seethala RR, Wang L, Cieply K, Sherer C, Joy C, Mills GB, Argiris A, Siegfried JM, Grandis JR, et al. Tumor epidermal growth factor receptor and EGFR PY1068 are independent prognostic indicators for head and neck squamous cell carcinoma. Clin Cancer Res. 2012; 18: 2278-2289.

74. Smilek P, Neuwirthova J, Jarkovsky J, Dusek 1, Rottenberg J, Kostrica R, Srovnal J, Hajduch M, Drabek J, Klozar J. Epidermal growth factor receptor (EGFR) expression and mutations in the EGFR signaling pathway in correlation with anti-EGFR therapy in head and neck squamous cell carcinomas. Neoplasma 2012; 59: 508-515.

75. Psyrri A, Lee JW, Pectasides E, Vassilakopoulou M, Kosmidis EK, Burtness BA, Rimm DL, Wanebo HJ, Forastiere AA. Prognostic biomarkers in phase II trial of cetuximab-containing induction and chemoradiation in resectable HNSCC: Eastern cooperative oncology group E2303. Clin Cancer Res. 2014; 20: 3023-3032.

76. Basavaraj C, Sierra P, Shivu J, Melarkode R, Montero E, Nair P. Nimotuzumab with chemoradiation confers a survival advantage in treatment-naïve head and neck tumors 
over expressing EGFR. Cancer Biol Ther. 2010; 10: 673681 .

77. Crombet T, Osorio M, Cruz T, Roca C, del Castillo R, Mon R, Iznaga-Escobar N, Figueredo R, Koropatnick J, Renginfo E, Fernández E, Alvárez D, Torres $\mathrm{O}$, et al. Use of the humanized anti-epidermal growth factor receptor monoclonal antibody $\mathrm{h}-\mathrm{R} 3$ in combination with radiotherapy in the treatment of locally advanced head and neck cancer patients. J Clin Oncol. 2004; 22: 1646-1654.

78. Licitra L, Störkel S, Kerr KM, Van Cutsem E, Pirker R, Hirsch FR, Vermorken JB, von Heydebreck A, Esser R, Celik I, Ciardiello F. Predictive value of epidermal growth factor receptor expression for first-line chemotherapy plus cetuximab in patients with head and neck and colorectal cancer: Analysis of data from the EXTREME and CRYSTAL studies. Eur J Cancer. 2013; 49: 1161-1168.

79. Burtness B, Goldwasser MA, Flood W, Mattar B, Forastiere AA. Phase III Randomized trial of cisplatin plus placebo compared with cisplatin plus cetuximab in metastatic/ recurrent head and neck cancer: an eastern cooperative oncology group study. J Clin Oncol. 2005; 23: 8646-8654.

80. Rodríguez MO, Rivero TC, del Castillo Bahi R, Muchuli CR, Bilbao MA, Vinageras EN, Alert J, Galainena JJ, Rodríguez E, Gracias E, Mulén B, Wilkinson B, de Armas EL, et al. Nimotuzumab plus radiotherapy for unresectable squamous-cell carcinoma of the head and neck. Cancer Biol Ther. 2010; 9: 343-349.

81. Del Campo JM, Hitt R, Sebastian P, Carracedo C, Lokanatha D, Bourhis J, Temam S, Cupissol D, De Raucourt D, Maroudias N, Nutting CM, Compton N, Midwinter D, et al. Effects of lapatinib monotherapy: results of a randomised phase II study in therapy-naive patients with locally advanced squamous cell carcinoma of the head and neck. Br J Cancer. 2011; 105: 618-627.

82. Romanitan M, Nasman A, Munck-Wikland E, Dalianis T, Ramqvist T. EGFR and phosphorylated EGFR in relation to HPV and clinical outcome in tonsillar cancer. Anticancer Res. 2013; 33: 1575-1583.

83. Hama T, Yuza Y, Saito Y, O-uchi J, Kondo S, Okabe M, Yamada H, Kato T, Moriyama H, Kurihara S, Urashima M. Prognostic significance of epidermal growth factor receptor phosphorylation and mutation in head and neck squamous cell carcinoma. Oncologist. 2009; 14: 900-908.

84. Kong A, Leboucher P, Leek R, Calleja V, Winter S, Harris A, Parker PJ, Larijani B. Prognostic value of an activation state marker for epidermal growth factor receptor in tissue microarrays of head and neck cancer. Cancer Res. 2006; 66: 2834-2843.

85. Chung CH, Ely K, McGavran L, Varella-Garcia M, Parker J, Parker N, Jarrett C, Carter J, Murphy BA, Netterville J, Burkey BB, Sinard R, Cmelak A, et al. Increased epidermal growth factor receptor gene copy number is associated with poor prognosis in head and neck squamous cell carcinomas. J Clin Oncol. 2006; 24: 4170-4176.

86. Temam S, Temam S, Kawaguchi H, El-Naggar AK,
Jelinek J, Tang H, Liu DD, Lang W, Issa JP, Lee JJ, Mao L. Epidermal growth factor receptor copy number alterations correlate with poor clinical outcome in patients with head and neck squamous cancer. J Clin Oncol. 2007; 25: 21642170 .

87. Gebhart E, Ries J, Wiltfang J, Liehr T, Efferth T. Genomic gain of the epidermal growth factor receptor harboring band $7 \mathrm{p} 12$ is part of a complex pattern of genomic imbalances in oral squamous cell carcinomas. Arch Med Res. 2004; 35 : 385-394.

88. Sato H, Uzawa N, Takahashi K, Myo K, Ohyama Y, Amagasa T. Prognostic utility of chromosomal instability detected by fluorescence in situ hybridization in fineneedle aspirates from oral squamous cell carcinomas. BMC Cancer. 2010; 10: 182.

89. Dionysopoulos D, Pavlakis K, Kotoula V, Fountzilas E, Markou K, Karasmanis I, Angouridakis N, Nikolaou A, Halogeras KT, Fountziulas G. Cyclin D1, EGFR and Akt/ mTOR pathway. Potential prognostic markers in localized laryngeal squamous cell carcinoma. Strahlenther Onkol. 2013; 189: 202-215.

90. Argiris A, Heron DE, Smith RP, Kim S, Gibson MK, Lai SY, Branstetter BF, Posluszny DM, Wang L, Seethala RR, Dacic S, Gooding W, Grandis JR, et al. Induction docetaxel, cisplatin, and cetuximab followed by concurrent radiotherapy, cisplatin, and cetuximab and maintenance cetuximab in patients with locally advanced head and neck cancer. J Clin Oncol. 2010; 28: 5294-5300.

91. Chau NG, Perez-Ordonez B, Zhang K, Pham NA, Ho J, Zhang T, Ludkovski O, Wang L, Chen EX, Tsao MS, Kamel-Reid S, Siu LL. The association between EGFR variant III; HPV, p16, c-MET, EGFR gene copy number and response to EGFR inhibitors in patients with recurrent or metastatic squamous cell carcinoma of haed and neck. Head Neck Oncol. 2011; 3: 1-11.

92. Cohen EE, Haraf DJ, Kunnavakkam R, Stenson KM, Blair EA, Brockstein B, Lester EP, Salama JK, Dekker A, Williams R, Witt ME, Grushko TA, Dignam JJ, et al. Epidermal growth factor receptor inhibitor gefitinib added to chemotherapy in locally advanced head and neck cancer. J Clin Oncol. 2010; 28: 3336-3343.

93. Licitra L, Mesia R, Rivera F, Remenár E, Hitt R, Erfán J, Rottey S, Kawecki A, Zabolotnyy D, Benasso M, Störkel S, Senger S, Stroh C, et al. Evaluation of EGFR gene copy number as a predictive biomarker for the efficacy of cetuximab in combination with chemotherapy in the firstline treatment of recurrent and/or metastatic squamous cell carcinoma of the head and neck: EXTREME study. Ann Oncol. 2011; 22: 1078-1087.

94. Su NW, Su NW, Leu YS, Lee JC, Liu CJ, Cheng CY, Lin JS, Chen YJ, Chen CK, Fang IC, Hsieh RK, Chang YF. EGF and EGFR genetic polymorphisms predict prognosis in locally advanced pharyngolaryngeal squamous cell carcinoma patients receiving postoperative concurrent chemoradiotherapy. Onco Targets Ther. 2014; 7: 2197- 
2204.

95. Bandrés E, Barricarte R, Cantero C, Honorato B, Malumbres R, Zàrate R, Alcalde J, Garcia-Foncillas J. Epidermal growth factor receptor (EGFR) polymorphisms and survival in head and neck cancer patients. Oral Oncol. 2007; 43: 713-719.

96. Klinghammer K, Knödler M, Schmittel A, Budach V, Keilholz U, Tinhofer I. Association of epidermal growth factor receptor polymorphism, skin toxicity, and outcome in patients with squamous cell carcinoma of the head and neck receiving cetuximab-docetaxel treatment. Clin Cancer Res. 2010; 16: 304-310.

97. Stoehlmacher-Williams J, Obermann L, Ehninger G, Goekkurt E. Polymorphisms of the epidermal growth factor receptor (EGFR) and survival in patients with advanced cancer of the head and neck (HNSCC). Anticancer Res. 2012; 32: 421-425.

98. Lee JW, Lee JW, Soung YH, Kim SY, Nam HK, Park WS, Nam SW, Kim MS, Sun DI, Lee YS, Jang JJ, Lee JY, Yoo NJ, et al. Somatic mutations of EGFR gene in squamous cell carcinoma of the head and neck. Clin Cancer Res. 2005; 11: 2879-2882.

99. Na II, Kang HJ, Cho SY, Koh JS, Lee JK, Lee BC, Lee GH, Lee YS, Yoo HJ, Ryoo BY, Yang SH, Shim YS. EGFR mutations and human papillomavirus in squamous cell carcinoma of tongue and tonsil. Eur J Cancer. 2007; 43: 520-526.

100. Bahassi el M, Li YQ, Wise-Draper TM, Deng L, Wang J, Darnell CN, Wilson KM, Wells SI, Stambrook PJ, Rixe O. A patient-derived somatic mutation in epidermal growth factor receptor ligand-binding domain confers increased sensitivity to cetuximab in head and neck cancer. Eur J Cancer. 2013; 49: 2345-2355.

101. Melchers LJ, Clausen MJ, Mastik MF, Slagter-Menkema L, Langendijk JA, van der Laan BF, van der Wal JE, van der Vegt B, Roodenburg JL, Schuuring E. Head and neck squamous cell carcinoma do not express EGFRvIII. Int J Radiation Oncol Biol Phys. 2014; 90: 454-462.

102. Khattri A, Zuo Z, Brägelmann J, Keck MK, El Dinali M, Brown CD, Stricker T, Munagala A, Cohen EE, Lingen MW, White KP, Vokes EE, Seiwert TY. Rare occurrence of EGFRvIII deletion in head and neck squamous cell carcinoma. Oral Oncol. 2015; 51: 53-58.

103. Wheeler SE, Egloff AM, Wang L, James CD, Hammerman PS, Grandis JR. Challenges in EGFRvIII detection in head and neck squamous cell carcinoma. PLoS One. 2015; 10: e0117781.

104. Trivedi S, Concha-Benavente F, Srivastava RM, Jie HB, Gibson SP, Schmitt NC, Ferris RL. Immune biomarkers of anti-EGFR monoclonal antibody therapy. Ann Oncol. 2015; 26: 40-47.

105. Mirghani H, Amen F, Tao Y, Deutsch E, Levy A. Increased Increased radiosensitivity of HPV-positive head and neck cancers: Molecular basis and therapeutic perspectives.
Cancer Treat Rev. 2015; 41: 844-852.

106. Lassen P, Primdahl H, Johansen J, Kristensen C, Andersen E, Andersen LJ, Evensen JF, Eriksen JG, Overgaard J. Impact of HPV-associated p16-expression on radiotherapy outcome in advanced oropharynx and non-oropharynx cancer. Radiother Oncol. 2014; 113: 310-316. 